\title{
Forces Driving Purchasing Behaviour of Tourists Hotels Along Tourist-Agricultural Supply Chain in Zanzibar
}

\author{
Kenneth M. K. Bengesi ${ }^{1}$ \& Juma O. Abdalla ${ }^{2}$ \\ 1 Department of Policy Planning and Management, College of Social Sciences and Humanities, Sokoine \\ University of Agriculture, Morogoro, Tanzania \\ ${ }^{2}$ Department of Agricultural Extension and Farmers Training, Kizimbani Agricultural Training Institute, Zanzibar, \\ Tanzania \\ Correspondence: Kenneth M.K. Bengesi, Department of Policy Planning and Management, Campus College of \\ Social Sciences and Humanities, Sokoine University of Agriculture, Morogoro, Tanzania.
}

\begin{tabular}{|c|c|c|}
\hline Received: February 16, 2018 & Accepted: April 4, 2018 & Online Published: May 7, 2018 \\
\hline doi:10.5539/ijms.v10n2p36 & URL: https://doi.org/1 & 9/ijms.v10n2p36 \\
\hline
\end{tabular}

\begin{abstract}
This paper examined forces driving tourists' hotels purchasing behaviour. The results revealed that the tourist hotels consider several factors before deciding to source vegetables and fruits from smallholder farmers. The most prominent factors for the tourist hotels to source vegetables and fruits were consistent quality, regular supply, compliance to legal practices, and hygiene conditions. Interestingly, proximity to the tourists' hotels and competitive price of fruits and vegetables were not among important driving forces contributing to the choice of sourcing points. This suggests that the tourist hotels are willing to pay premium prices so long they are assured of quality and regular supply, comply to legal practices and observe hygiene conditions. With the fact that smallholder farmers lack access to appropriate market information, produce at subsistence level and lack logistic infrastructure this call for a change of mind-set among smallholder farmers and position strategically to take advantage of emerging markets.
\end{abstract}

Keywords: agriculture, emerging tourism markets, purchasing behaviour, tourism, supply chain

\section{Introduction}

Tourism is certainly one of the huge and an important economic activity in the world, contributing a major part of the global economy. According to Lew (2011), tourism is among the top five sources of international export income for more than 80 per cent of countries in the world. International export encompasses all the receipts that a country receives from money that tourists spend at the destination. In 2013, travel and Tourism's total contribution to the global economy rose to 9.5 per cent of global GDP (USD 7 trillion), created nearly 266 million jobs in the world and recorded faster growth than any other economic sectors (Mnguni \& Giampiccoli, 2016; Du et al., 2016; Che Chou, 2013). Christie et al. (2013) pointed that tourism across sub Saharan Africa created 5.3 million direct jobs and contribute 2.7 per cent to the GDP. In this view, the sustained demand for Tourism, coupled with its ability to generate high levels of employment continues to prove its importance in economic development.

For developing countries with high potential for tourism attraction like Tanzania and Zanzibar in particular; the importance of the tourism lies not only to its contribution to the economic growth but also in the fact that given the right circumstances the tourism growth can support structural foundations, influence the economic and cultural progress of society, and improving the welfare of the local population. In view of this argument, Du et al. (2016) and Belloumi (2010) echoed similar view that destinations use tourism as a way to use their comparative advantages in natural and cultural supply side resources and complementarity with other economic activities to stimulate local economy, generate foreign exchange, create jobs, and enhance government revenue through taxes. These views, imply that well planned tourism may yield multiple benefits to complement economic activities such as transport, agriculture, hotels, arts and leisure to mention a few.

In view of the above, strengthening the linkage between tourism and other sectors especially agriculture becomes important for tourism to contribute significantly to the overall economic growth and poverty reduction in Zanzibar. This follows the fact that the agricultural sector in Zanzibar plays an important role in the economy because of its significant contributions to the employment and income generation to majority of the population. According to 
Anderson \& Juma (2011) about 70 per cent of the population in Zanzibar depends directly or indirectly in agriculture sector for their livelihood. With this understanding, well-planned tourism sector has the potential to lift many poor out of poverty and thereby contribute to economic growth and improve their livelihood. Supporting this argument Rueegg (2009) pointed that the tourism industry offer opportunities to stimulate local agricultural development through backward linkages that allow local farmers to supply food needs of tourism establishments such as hotels and lodges in their locality. Creating and strengthening linkages between the tourism and agriculture especially food sector can provide an adjacent market for locally produced agricultural food crops and beverage products which are likely to benefit the majority of the local community in the destination and sustain their livelihood (Hall \& Lew, 2009; Fayissa et al., 2008; Cárdenas-Garcia et al., 2013).

While the conceived potential benefits of tourism to the local economy and the livelihood of the smallholder farmers in Zanzibar is high, the structure of tourism and agricultural supply chain is not clearly articulated. The paucity of information with regards to the importance of linkages between tourism and agriculture might be attributed by inadequate research in the fields of tourism and complementary sectors. Along the same line Torres (2002) argued that most research examining tourism and agriculture linkages have focused on hotels food procurement patterns while failing to address the main force driving hotel purchasing behaviour, tourists consumption and preferences. This paper argue that research emphasizing on procurement patterns rather than forces driving hotel's purchasing behaviour has placed smallholder farmers on the disadvantage side for failing to harness and sustaining benefits resulting along the agriculture-tourism supply chain.

Understanding forces driving purchasing behaviour among tourists' hotels is crucial for strategic engagement of the smallholder farmers along the tourism-agriculture supply chain. In this view, this paper gives a thorough analysis of interface between tourism and agriculture, forces driving tourists' hotels purchasing behaviour and provides an important framework to explain the potential benefits resulting from this linkage of which smallholder farmers can maximize the economic benefits. This paper also presents new areas for intervention if at all the sector has to make multiplier effects to the economy and livelihood of the smallholder farmers in Zanzibar.

\section{Liretature Review}

\subsection{An Overview of Agriculture in Zanzibar}

Zanzibar is a small Island with just over a million inhabitants, the majority of whom are subsistent farmers. The agriculture sector contributes an average of 30 per cent of the total GDP in Zanzibar (Office of Chief Government Statistical [OCGS], 2013). This contribution is attributed by its dominance in the earning of foreign exchange, which is currently accounting for over 70 per cent. However, the country depends on limited agricultural commodities as primary export items confined to cloves and seaweed. Other potential export commodities include spices, and marine products, which have so far registered insignificant, export proportion (Anderson, 2013; Zanzibar Association of Tourism Investors [ZATI], 2009). Agriculture employs about 60 per cent of Zanzibar's labour force, and on average, 70 per cent of the population depends directly or indirectly in the agriculture sector for their livelihood (OCGS, 2013; Anderson \& Juma, 2011).

The subsistence nature of agriculture in Zanzibar is characterized by small-scale farming, with low productivity of land, labour and other inputs (Anderson \& Juma, 2011; RGZ, 2010). This is caused among others by limited capacity of institutions coordinating the sector and lack of framework for inter-sector linkage to create synergy among actors to maximize economic benefits. Voluntary Service Overseas (VSO, 2015) examined the commercial agriculture for smallholder farmers in Zanzibar and observed that the success in terms of connecting smallholder farmers to the end market such as tourist hotels is limited. In the current model, this is being done through farmers associations such as UWAMWIMA, TAHA, JUWA and UWZ. These organizations not only lack required capacity but also they lack entrepreneurial mind-set to overcome production and supply chain barriers. According to Bengesi \& Le Roux (2014a) a well-planned framework creates beneficial networks, which are likely to motivate smallholder farmers to overcome production barriers and produce for commercial purpose. Commercial production requires entrepreneurial orientation that motivates farmers to produce adequate for the market to fill the current deficit of vegetables and fruits in Zanzibar that stand at 80 per cent (VSO, 2013).

According to Zanzibar Association of Tourism Investor (ZATI, 2009), Zanzibar typically consumes more staple foods, vegetables and fruits than it produces and she has been forced to embark on import mainly from Tanzania inland, a situation that has not benefited the local smallholder farmers in Zanzibar. Supporting this argument VSO (2013) reported that about 80 per cent of vegetable and fruits supplied to hotel industry are not from Island. This is not to say that the deficits of food supply in Zanzibar is due to low agriculture potential; on contrary, Zanzibar has a huge potential for developing agriculture, taking into account its comparative advantage of having good soils and rainfalls pattern to support crop production. Failure of local smallholder farmers in Zanzibar to benefit from the 
emerging tourism market raises a pertinent question on:

\section{Question 1(a): What is the structure of tourism and agriculture supply chain in Zanzibar?}

Question 1(b): Does the existing supply chain provide any opportunities for smallholder farmers to takeadvantage of emerging market in the tourism industry?

Responding to these questions require a clear understanding of the existing structure of the tourism and agriculture supply chain to set a context for a framework to explain the potential benefits resulting from agriculture and tourism linkage and how best the smallholder farmers can take advantage of emerging opportunities in the tourism industry.

\subsection{Tourism Industry in Zanzibar}

Tourism is the fastest growing sub-sector within the service sector in Zanzibar's economy, and it is one of the most important sectors with great potentials for growth. The literature indicates that the tourism account for about $70 \%$ of Zanzibar's foreign currency earning, 51\% of GDP and over $60 \%$ of all approved foreign direct investment (MFEA, 2009; MFEA, 2011; Steck et al., 2010). Recent data by the Zanzibar Commission for Tourism showed that tourism is increasingly becoming a leading economic sector in the island, providing 11,500 workers with direct employment and an additional 45,000 people engaged in tourist activities (RGZ, 2009). Zanzibar is a strategic tourism destination with numerous historical and cultural tourists sites, which are famous worldwide.

The potential tourist attractions promoting growth of tourism in Zanzibar are Stone Town with its wealth of historical buildings and traditional Swahili culture; marine environment in both Unguja and Pemba characterized by coral reefs suitable for snorkelling and diving; offshore islands and coral reefs (Changuu, Chumbe, Mnemba); big game fishing; sea turtle and dolphins; sand beaches and extensive water areas used mostly for traditional fishing activities ZCT (2011). Other attractions include historical cultural sites, such as the ruins of Maruhubi Palace, the ruins of Mtoni Palace, the Kidichi and Kizimbani Persian Baths, and the Mangapwani Slave Cave. There are also Spice Tours, Jozani and Ngezi Forest Reserves (renowned for their diverse and rare botanical species and the presence of monkeys, fruit bats, antelopes, wild pigs, and a wild variety of birds). Arts and crafts, the Pemba essential oils factory and eco-tourism attractions complete the list. The foregoing endowments and others not mentioned here collectively confer comparative advantage in tourism on Zanzibar.

Existence of tourist attractions coupled with the improved infrastructure such as modernized airport, roads and friendly environment (OCGS, 2013) has motivated tourists to visit the isles, which recorded an annual increase of about 9.6 per cent. Continuous growth of tourism sector in Zanzibar recorded an increase of annual tourists visiting Zanzibar from 86, 918 in 1999 to 294,000 in 2015 (Revolutionary Government of Zanzibar [RGZ], 2016). The increase in tourist visitors signifies a need to increase the share of local agricultural products such as vegetables and fruits in local tourism market to cope with the growing tourist population and reduce import from other Countries (Zanzibar Commission for Tourism [ZCT], 2011). However, the smallholder farmers in Zanzibar have not benefited from the local tourism industry despite the fact that tourism consumes large proportion of agricultural products such as fruits and vegetables (Revolutionary Government of Zanzibar [RGZ], 2004). While it is not clear why smallholder farmers are not taking advantage of emerging market in the tourism industry, it is compelling to believe that understanding of forces driving purchasing behaviour of the tourists' hotels is likely to open up for strategic engagement of the smallholder farmers to take advantage of the agriculture and tourism supply chain. However, this raises the second question on;

\section{Question 2: Which forces are driving purchasing behaviour of the tourist hotels?}

\subsection{Economic Benefit of Tourism Industry in Zanzibar}

In recognition of the importance of tourism sector in Zanzibar economy the government has launched several initiatives to create an enabling environment for sustainable tourism development. Among these initiatives include the adoption of the Zanzibar Strategy for Growth and Reduction of Poverty commonly in Kiswahili known as "Mkakati wa Kukuza Uchumi Zanzibar" (MKUZA III) which advocates for inter-sectorial linkages (RGZ, 2016) and other government policies related to tourism development, such as the Zanzibar Tourism Master Plan (United Republic of Tanzania [URT], 2003) and Zanzibar Tourism Policy (RGZ, 2004). The initiatives carry the assumption that the economic benefits of the tourism sector will stimulate the development of other economic sectors such as agriculture through increased demand for local commodities (Anderson \& Juma, 2011).

While there is no current data directly linking the growth of tourist arrivals to Zanzibar's economic growth profile, one can clearly associate growth in some sub-sector activities with growth in tourism (MFEA, 2009). Some of these activities include hotels and restaurants, transport and communications, construction, manufacturing, including arts and crafts (production of wooden chests and doors, picture frames, brass, copperware and jewellery) 
as well as growth in agricultural production (for example, staple foods, horticulture, spices, and so forth). The evidence includes the 9 per cent average annual growth in hotels and restaurants, the 17 per cent average annual growth in transport and communication, the 18 per cent average annual growth in construction, as well as the increased demand for agricultural products (ZCT, 2011).

Although there is a growing consensus that increased demands of agricultural products from tourism should be met by local agricultural supplies as asserted by several authors (Ashley et al., 2006; Ruegg, 2009; Mshenga \& Owuor, 2009; Mshenga, 2010), on the other hand, other scholars found that the empirical part for achieving these benefits, for the most part, have been less and less (Timms \& Neill, 2011; Rogerson, 2012). The equivocal results, suggest that to increase the positive impacts of tourism on poor people, engagement of smallholder farmers in the linkages between tourism sector and agricultural enterprises is crucial (Bengesi \& Le Roux, 2014a). However, the basic question remain:

Question 3: How can the smallholder farmers strategically be engaged in the tourism-agriculture supply chain to maximize economic benefits?

\section{Method}

\subsection{Study Context}

The study was conducted in Zanzibar, which consists of two main islands, Unguja and Pemba, and several other smaller islets in the Indian Ocean. This study covered all important tourism areas in Unguja Island namely Stone Town and Suburbs, North-East Coast and South-East Coast with respect to tourism domination, presence of on-going horticultural activities, presence of tourism establishments and availability of study data compared to Pemba Island.

The Stone Town and Suburbs tourist zone forms the urban part of Zanzibar. It consists of several tourism attractions particularly the historic sites and the design of the old buildings, the Old Fort, Palace Museum, and the Anglican Cathedral with slave market. The dhow harbour and Forodhani Garden are also tourist attractions. The North-East Coast tourist zone stretched to Nungwi Strip, Matemwe, Pwani Mchangani, Kiwengwa, Pongwe, Chwaka and Uroa. It contains some of the popular beach destinations (for example Kendwa) for back packers and the young budget travellers. The South-East Coast tourist zone starts from the Eastern Coast of Island from Michamvi to Kizimkazi and in the South it covers Bwejuu, Paje and Jambiani. This zone contains some of the popular beach destinations with several attractive tourist establishments.

\subsection{Research Design and Sampling Procedure}

The study adopted a cross sectional research design to assess and analyse forces driving purchasing behaviour of tourists' hotels to set a context for strategic engagement of the smallholder farmers to tape existing potential along the tourism-agriculture supply chain. The study involved smallholder farmers dealing with fresh fruits and vegetable production with less than 5 hectares and the hotels and restaurants were those served foreign tourists. To meet the study objective, purposive sampling was done for tourist hotels and systematic random sampling for smallholder farmers. Therefore, sample sizes of 85 out of 750 smallholder farmers and 31 out of 300 tourists' hotels, respectively were used for this study.

\subsection{Measurement of Key Variables}

The study involved several key variables, which is important to indicate how were measured to ensure credibility of the findings. Among the key variables involved in this study include proximity of hotels to the sourcing points, consistent quality and regular supply of vegetables and fruits, hygiene conditions, acquisition of legal status, and competitive price of vegetables and fruits. While researchers understand that these variables may have different meaning in different settings, which may lead into a different way of measuring them. The measurement of these variables explained under this section serve the purpose of this study.

With regards to the proximity of hotels to the sourcing points was established by asking respondents the distance between smallholder farmers and the tourist hotels. The distance within 5 kilometres between hotels and farmers was considered to be a proximity distance and anything beyond 5 Kilometres was considered non-proximity. The consistency quality of supply was measured by asking respondents on whether farmers were able to meet set standards of the hotels, which are fresh vegetables and fruits, consistency size and colour, clean, and long shelf life. The regular supply was measured by establishing frequency of supply in a calendar year by providing adequate products of acceptable quality. On the other hand, acquisition of legal status was measured on the basis of an enterprise registered for tax purposes and compliance to legal business practices such as offering of sales receipts; while the hygiene conditions were measured on the compliance to hygiene standards set by the Tanzania Food and Drugs Authority (TFDA). Moreover, the competitive price was measured by establishing affordable price of a 
given product compared with different sourcing points without compromising the quality.

\subsection{Data Sources, Processing and Analysis}

The study used both primary and secondary data. The information was collected from smallholder farmers, tourist hotel managers/owners, key informants (that is agricultural extension officers) and reports from several institutions dealing with tourism and agriculture. The data analysis adopted mapping procedure for research question 1 of which the key actors along the tourist-agricultural supply chain were identified and allocated to appropriate node and potential opportunities were identified along the supply chain. Data for the second question was analysed using descriptive analysis coupled with the score ranking to identify forces driving tourists' hotels purchasing behaviour that subsequently determined strategic position for smallholder farmers to take advantage of the emerging tourist market.

\section{Results}

\subsection{General Overview of Results}

This paper gives a critical analysis of the structure of tourism-agricultural supply chain, forces driving purchasing behaviour of the tourists' hotels in Zanzibar and identifies opportunities through which smallholder farmers can take advantage to maximize economic benefits in the tourism emerging markets in Zanzibar. To achieve this objective, the paper examined the producer-market linkage with the emphasis on the structure of tourism-agriculture supply chain of agricultural produce (i.e., fruits, and vegetables) from smallholder farmers to different market outlets including tourists' hotels, identify potential opportunities along the supply chain, perceived factors driving the purchasing behaviour of the tourists hotels, and finally draw recommendations on how strategically smallholder farmers can be positioned to maximize economic benefits from the emerging tourists market in Zanzibar.

\subsubsection{Structure of the Tourism-Agriculture Supply Chain in Zanzibar}

The structure of tourism- agriculture supply chain was examined with the focus on the supply chain of agricultural produce from producers to different end markets including the tourist hotels. The essence of this analysis was to identify existing potential market opportunities along the supply chain and set a context on how best the smallholder farmers can be engaged to benefit from the emerging market in the tourism industry. Figure 1 presents the structure of the tourism-agriculture supply chainspecifically for vegetables and fruits produced by smallholder farmers and supplied to different market outlets and tourist hotels in Zanzibar.

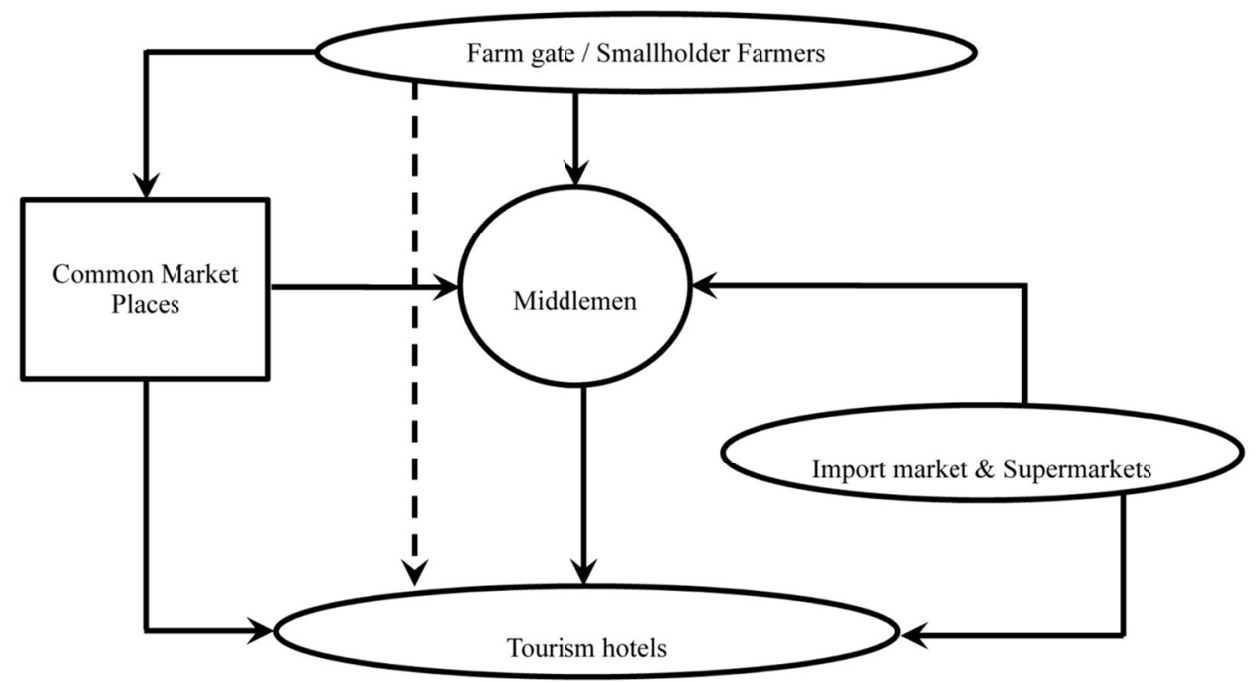

Figure 1. Structure of Tourism-Agriculture Supply Chain in Zanzibar

The results revealed that smallholder farmers have four possible market outlets for agricultural produce namely tourist hotels, common market places, middlemen and other markets i.e. regional markets. On the other hands, the tourist hotels, which are on the demand side of farmers produce, have four sourcing points for vegetables and fruits namely farmers, market places, middlemen and other sources such as import markets and supermarkets. The middlemen can source vegetables and fruits from farmers, common market places, and import markets or from all three sources and supply to the tourist hotels. 
Table 1. Market opportunities for smallholder farmers

\begin{tabular}{|c|c|c|}
\hline & Potential Opportunities & Specific Market Outlets \\
\hline 1 & Local markets & $\begin{array}{ll}\text { - } & \text { Tourist hotels } \\
\text { - } & \text { Common Market places } \\
\text { - } & \text { Middlemen } \\
\text { - } & \text { Other types of markets i.e., import markets, supermarkets and individual buyers }\end{array}$ \\
\hline 2 & Emerging regional markets & $\begin{array}{ll}\text { - } & \text { East African Common Market } \\
\text { - } & \text { COMMESA } \\
\text { - } & \text { SADC }\end{array}$ \\
\hline
\end{tabular}

\subsubsection{Market Opportunities for Smallholder Farmers in Zanzibar}

The findings on Table 1 show that there are mainly two potential opportunities, which are within reach of the smallholder farmers in Zanzibar. These are local market, which constitutes tourists' hotels, common market places, middlemen and other types of markets such as supermarkets, individual buyers and the like.

The second source of potential market opportunity is the emerging regional markets such as East African Common Market, COMMESA, and SADC. The study observed that emerging regional markets opportunities are appropriate for Zanzibar since Zanzibar is a member state of the Tanzania Union government, which is a member of the East African Community, COMMESA, and SADC. The mentioned regional markets have developed common market protocols in favours of the member states.

\subsection{Forces Driving Purchasing Behaviour of Tourists' Hotels}

The forces driving purchasing behaviour of tourists' hotels were examined to identify motivation factors driving tourist managers to purchase fruits and vegetables from different sourcing points. This analysis was crucial for strategic engagement of the smallholder farmers to take advantage of the emerging market (Bengesi \& Le Roux, 2014b). Results on Table 2 revealed that each market outlet has specific driving forces motivating or demotivating tourist hotel managers to buy or not to buy agricultural produce. In the course of the interview, the tourist hotels managers pointed that they prefers to source agricultural supplies from other sources such as import markets and supermarkets, followed by middlemen, common market and lastly from smallholder farmers (Table 2).

Table 2. Forces driving purchasing behaviour of tourists' hotels $(n=116)$

\begin{tabular}{|c|c|c|c|}
\hline \multirow{2}{*}{$\begin{array}{l}\text { Sourcing } \\
\text { Point }\end{array}$} & \multicolumn{2}{|l|}{ Driving forces } & \multirow[b]{2}{*}{ Ranking } \\
\hline & Motivation factors & Demotivation factors & \\
\hline $\begin{array}{l}\text { Import } \\
\text { market }\end{array}$ & $\begin{array}{l}\text { Consistent quality } \\
\text { Reliable / Consistent supply } \\
\text { Meet taste and preference of customers with diverse culture } \\
\text { Involve legal and binding contract } \\
\text { Offers legal receipts } \\
\text { Verified quality and standards } \\
\text { Graded/sorted vegetables and fruits } \\
\text { Modern storage facilities and packaging materials }\end{array}$ & $\begin{array}{l}\text { Long procedure to comply with import } \\
\text { conditions } \\
\text { In case of bleach of contract there are costs } \\
\text { implied } \\
\text { Failure to meet taste and preference for local } \\
\text { customers }\end{array}$ & 1 \\
\hline $\begin{array}{l}\text { Middle } \\
\text { men }\end{array}$ & $\begin{array}{l}\text { Reliable supply } \\
\text { Good quality of vegetables \& fruits } \\
\text { Involve legal binding contract } \\
\text { Convenient to deal with a single supplier } \\
\text { Provide legal receipt }\end{array}$ & $\begin{array}{l}\text { Implied costs in case of bleach of contract } \\
\text { Sometimes affected by local seasonal supply } \\
\text { Face challenges to ascertain health and safety } \\
\text { standards }\end{array}$ & 2 \\
\hline $\begin{array}{l}\text { Common } \\
\text { market }\end{array}$ & $\begin{array}{l}\text { Proximity to the sourcing point } \\
\text { Wide range of choices for common vegetables and fruits }\end{array}$ & $\begin{array}{l}\text { No graded / sorted products } \\
\text { No modern storage facilities } \\
\text { Seasonal availability of some vegetables and } \\
\text { fruits } \\
\text { Limited hygiene conditions }\end{array}$ & 3 \\
\hline Farm gate & $\begin{array}{l}\text { Supply fresh vegetables and fruits } \\
\text { Proximity to the sourcing point } \\
\text { Offers competitive price compared to other sources } \\
\text { Supply local consumer preference }\end{array}$ & $\begin{array}{l}\text { No legal receipts are provided } \\
\text { No proper storage facilities } \\
\text { No proper packaging materials } \\
\text { No modern transport facilities } \\
\text { Seasonal suppliers } \\
\text { Produce at subsistence level } \\
\text { Limited hygiene conditions } \\
\text { Lack access to appropriate market information }\end{array}$ & 4 \\
\hline
\end{tabular}


The critical examination of the driving forces on purchasing behaviour of the tourists' hotels showed that most hotels' managers would prefer other sources such as import markets and supermarkets due to consistent supply and quality, wide choice of produce that meet tastes and preferences of their customers with diverse culture, most importers and supermarket stores are legal firms and adhere to legal business practices, offer products of verified quality and standards, and have modern storage facilities to keep longer the shelf life of vegetables and fruits. On the other hands, the second preference i.e., the middlemen had almost similar driving forces to the first preference the other sources (i.e., import markets and supermarkets) such as reliable supply and quality, convenience of dealing with a single supplier, operating in the secure environment (legal binding contracts), and availability of legal receipts in any transaction.

In view of the common market place the observed forces were the proximity to the sourcing points, wide range of choices for common vegetables and fruits. Moreover, the farm gate sourcing point was characterised with three basic forces such as supplying of fresh vegetables and fruits, proximity to the sourcing point, offers competitive price, and supply local consumers preference produces.

\subsection{Position of Smallholder Farmers}

The position of smallholder farmers was examined based on factors demotivating tourists' hotels to purchase agricultural produce from them. The results in Table 2 clearly indicate that despite the fact that smallholder farmers supply fresh vegetables and fruits, located at proximity distance to hotels, and offers competitive price compared to other suppliers, they lack legal status of firms, produce at subsistence level that does not ensure reliable supply, operate in an environment with limited hygiene conditions and lack proper storage facilities. Most of these factors might be attributed by the fact that smallholder farmers lack access to market information to understand what exactly the market demands.

\section{Discussion}

The structure of the tourism-agriculture supply chain was examined to identify different potential market outlets through which smallholder farmers sale their vegetables and fruits and the potential sourcing points from which the tourists' hotels purchase their vegetables and fruits. The results recorded four market outlets for smallholder farmers' namely common market places, middlemen, tourists' hotels and other markets i.e. regional markets. On the other hands, the findings revealed four potential sourcing points (i.e., supermarkets and import markets, middlemen, common market placed, and smallholder farmers) through which tourists' hotels buy vegetables and fruits for their hotels. The identified market outlets provide enormous potential opportunities for smallholder farmers to supply agricultural produce to different consumers.

Despite all the identified potential opportunities, the smallholder farmers have not adequately exploited the emerging market in the tourist industry. The findings revealed that Zanzibar still rely on the import for over $80 \%$ fruits and vegetables from the import market. The findings revealed further that the tourists hotels' managers prefers to source agricultural supplies from other sources i.e., import markets and supermarkets, followed by middlemen, common market and lastly from smallholder farmers (Table 2). The advanced reasons by managers for their preference are that tourist hotels prefer import markets and supermarkets due to assurance of consistent quality and supply, like to operate with legal firms, and likelihood to source products, which meet taste and preference of customers with diverse culture. Given the fact that the majority of tourists are foreigners who are concern with health and food safety issues or demand some fruits and vegetables, which are not produced in Zanzibar, import market is appropriate to fill this gap.

The smallholder farmers hardly meet these requirements partly due to lack of extension services and access to appropriate market information. Consequently, the smallholder farmers are less informed about what and how much the market demands. They produce at subsistence level due to operating in smallholdings and reliance on rain fed agriculture, have limited hygiene conditions, do not offer sales receipts in any business transaction which is crucial for financial accountability by any legal businesses like tourist hotels. The lack of proper packaging and storage materials, and reliable transportation facilities compound the problem of ensuring reliable supplies of fresh agricultural produce to destination market (i.e., tourist hotels). In this context, despite the competitive farm gate price and proximity to the hotels it is still difficult for them to sustain regular supply and maintain required quality standards, which is necessary for the tourists' hotels.

The expanding domestic and regional market for foods especially for marine, livestock and vegetable products is another opportunity for smallholder farmers in Zanzibar. According to URT (2010) in terms of regional trades Tanzania including Zanzibar is a member of South African Development Community (SADC) and the East African Community (EAC). The two trade blocks (that is SADC and EAC) have important prospects for Zanzibar agricultural trade performance, given the long established trading relationships between Eastern African countries 
and the increasing role of Southern Africa in realizing SADC Trade protocol. The EAC member countries have harmonized their tariff and customs regimes and have enacted a common external tariff (CET) (East Africa Business Council, (EABC), n.d.). An expanded Free Trade Area under COMESA-EAC-SADC is another important opportunity to tape the potential trade and market opportunities.

When asked whether hotels consider competitive price to source fruits and vegetables from smallholder farmers at farm gate price. The hotel managers argue that in most cases price variation is of less importance if they are assured of reliable supplies and quality. These findings suggest that if smallholder farmers are to win the tourist emerging market among other factors quality of produce, reliability of supply, hygiene conditions, and acquisition of legal status of their enterprise should be given priority. This can be achieved if smallholder farmers are connected to the reliable extension services and forge linkage with the tourist hotels' managers for reliable market information. The experience of imperfect market information among smallholder farmers might have created barriers to smallholder farmers to understand both the cultural and the market dynamics such as market demands in terms of quality and quantities, pricing of agricultural produces, food taste and preferences of tourists with diversity culture, and specific requirements of the tourists hotels.

The imperfect market information has placed smallholder farmers on a dark side and farmers have failed to make rational decisions on what and how much to produce for the end market including the emerging tourist market. Coupled with the failure of smallholder farmers to sort and grade their produces, being seasonal producers due to reliance on rainfall, and production at subsistence level this may explain why smallholder farmers in Zanzibar have failed to take advantage of the emerging market in the tourist industry. Given the fact that hotels are not regarding competitive price to be barrier this suggest that the hotels are willing to offer premium price for suppliers with assurance of consistent supply and quality. In this case, change of mind-set and practices among smallholder farmers is crucial to take advantage of emerging markets in both the regional markets and tourism industry in Zanzibar.

These findings are crucial in the current literature of tourism of which there are several debates on whether tourism has significant contribution to the growth and improvement of the livelihood especially in developing countries (Lew, 2011). In view of these findings this paper argues that the benefits of inter-face between tourism and agriculture are not automatic; it is necessary for smallholder farmers to understand the dynamics and the requirement of the tourism sector for strategic response. For example, it is clear that the tourist hotels host customers of diverse culture with different taste and preferences, demand high quality products, and are concern with health and food safety issues. In this regards, smallholder farmers should understand the market demands and the required standards to be able to fit well in the supply chain.

\section{Conclusion and Recommendations}

The paper established and mapped a supply chain of fresh vegetables and fruits from smallholder farmers to different selling points and sourcing options for the tourists' hotels in Zanzibar. Determining forces driving tourists' hotels purchasing behaviour the findings observed that the tourist hotels consider several factors before deciding to source vegetables and fruits from local producers. However, the most prominent forces for the tourist hotels to source from local producers were consistent quality of vegetables and fruits, regular supply of vegetables and fruits, hygiene conditions, and legal status of firm. Interestingly, competitive price and proximity to sourcing points were not among important forces driving hotels managers to source vegetables and fruits from smallholder farmers. This suggest that the tourist hotels are willing to pay premium prices as long as they are assured of quality products, regular supply and operate with the legal firm.

The observed weak link between hotels and smallholder farmers is attributed by several factors among few includes failure of smallholder farmers to produce adequate amount to ensure regular supply and comply with the quality standards of the tourists hotels. This might be explained by the experience of imperfect market information among smallholder farmers that accounting for failing to understand what and how much to produce for the end market and lack of logistic infrastructure among smallholder farmers to ensure timely supply of fresh produce to the end market. With the fact that subsistence farmers lack logistic infrastructure and produce less and work in isolation it has always been a challenge to supply timely and adequate amount of vegetables and fruits required by the end markets. Coupled with the failure to produce official transaction receipts to the hotels, which is crucial for financial accountability and control purposes on the side of the tourists' hotels; it has always limited smallholder farmers to benefit from the emerging tourists markets.

Based on the findings, this paper recommends that smallholder farmers should change their mind-set and put emphasis on entrepreneurial farming to cope with the new changes occurring in the tourist industry. With the view that tourists come from different countries this suggests that their taste and preferences of foods are diverse and 
both hotels and farmers require an innovative way of dealing with. This may requires farmers to think beyond producing quality products but also producing adequate varieties to meet diverse taste and preferences of tourists and forge strategic alliance with suppliers to benefits from efficient logistic infrastructure to ensure timely supply of locally produced vegetables and fruits to the end market. Entrepreneurial farming inculcate commercial mind set among smallholder farmers to abide to the principles of agribusiness that shift firms from informal enterprise to formal ones and be able to provide legal business documents such as sales receipts, and delivery note essential for the books of accounts. These documents have been among barriers to trade between smallholder farmers and the tourist's hotels in Zanzibar.

This paper also recommends further studies on agricultural products market channels to compare profits accrued in different supply chains and market segments. The exploration of these market segments and supply chains will assist smallholder farmers to identify the most profitable option for them to take advantage.

\section{References}

Ali, M., Farooq, U., \& Shih, Y. (2002). Vegetable Research and Development in the ASEAN Region: A guideline for setting priorities. In C. G. Kuo (Ed.), Perspectives of ASEAN Cooperation in Vegetable Research and Development (pp. 20-64). AVRDC, Shanhua, Taiwan.

Anderson, W. (2013). Leakages in the Tourism Systems: Case of Zanzibar. Tourism Review, 68(1), 62-76. https://doi.org/10.1108/16605371311310084

Anderson, W., \& Juma, S. (2011). Linkages at Tourism Destinations: Challenges in Zanzibar. Journal of Tourism Research, 3(1), 27-41.

Ashley, C., Goodwin, H., McNab, D., Scott, M., \& Chaves, L. (2006). Making Tourism Count for the Local Economy in the Caribbean: Guidelines for good practice. Retrieved from www.propoortourism.org.uk/caribbean/brief3w.pdf.

Belloumi, M. (2010). The Relationship between Tourism and Receipts, Real Effective Exchange Rate and Economic Growth in Tunisia. International Journal of Tourism Research, 12, 550-560. https://doi.org/10.1002/jtr.774.

Bengesi, K. M. K., \& Le Roux, I. (2014a). Networking Capability of Small and Medium Enterprises (SME) Performance. International Journal of Business and Social Science, 5(2), 189-200.

Bengesi, K. M. K., \& Le Roux, I. (2014b). Strategic Entrepreneurial Response of Small and Medium Enterprises in Developing Economies. International Journal of Business and Management, 9(2), 153-165. http://dx.doi.org/10.5539/ijbm.v9n2p153.

Cárdenas-Garcia, P. J., Sánchez-Rivero, M., \& Pulido-Fernández, J. I. (2013). Does Tourism Growth Influence Economic Development? Journal of Travel Research, $X X(\mathrm{X}), 1-16$.

Che Chou, M. (2013). Does Tourism Development Promote Economic Growth in Transition Countries? A Panel Data Analysis, Economic Modelling, 33, 226-232. https://doi.org/10.1016/j.econmod.2013.04.024

Christie, I., Fernandes, E., Messeli, H., \& Twining-Ward, L. (2013). Tourism in Africa: Harnessing tourism for growth and improved livelihoods. International Bank for Reconstruction and Development. The World Bank, Washington.

Du, D., Lew, A. A., \& Ng, P. T. (2016). Tourism and Economic Growth. Journal of Travel Research, 55(4), 454-464. https://doi.org/10.1177/0047287514563167

East African Business Council [EABC]. (n. d.). East African Community Common Market protocol. Retrieved from http://www.eabc.info/uploads/SCMP_Final_High_Resolution_Version_16.pdf

Fayissa, B., Nsiah, C., \& Tadasse, B. (2008). Impact of Tourism on Economic Growth and Development in Africa. Tourism Economics, 14(4), 807-818.

Hall, C. M., \& Lew, A. A. (2009). Understanding and Managing Tourism Impacts. Oxford: Routledge.

Honeck, D. (2008). LDC Poverty Alleviation and the Doha Development Agenda: Is Tourism being neglected? World Trade Organization.

Krstic, B., Joranovic, S., Jankovic-Milic, V., \& Stanisic, T. (2016). Examination of Travel and Tourism Competitiveness Contribution to National Economy Competitiveness of Sub saharan Africa Countries, Development Southern Africa, 33(4), 470-485. https://doi.org/10.1080/0376835X.2016.1179103

Lew, A. A. (2011). Tourism Role in the Global Economy. Tourism Geographies, 13(1), 148-151. 
https://doi.org/10.1080/14616688.2010.531046

Luvanga, N., \& Shitundu, J. (2003). The Role of Tourism in Poverty Alleviation in Tanzania. Research report No. 4. On poverty alleviation. Mkuki na Nyota Publishers Limited, Dar es Salaam, Tanzania.

Meyer, D. (2006). Caribbean Tourism, Local Sourcing and Enterprise Development: Review of the literature. Working Paper No.18, Pro-Poor Tourism Partnership, London.

Meyer, D. (2007). Pro-poor Tourism: From Leakages to Linkages: A Conceptual Framework for Creating Linkages between the Accommodation Sector and Poor Neighbouring Communities. Current Issues in Tourism, 10, 558-583. https://doi.org/10.2167/cit313.0

Ministry of Finance and Economic Affairs [MFEA]. (2009). Growth Drivers and their Implications for Poverty Reduction. Ministry of Finance and Economic Affairs. Zanzibar.

Ministry of Finance and Economic Affairs [MFEA]. (2011). Ministry of Finance and Economic Affairs, Zanzibar. Zanzibar Economic Bulletin, 4(1), 24-34.

Mitchell, J. (2006). Linkages and leakages: local supply and imports, Overseas Development Institute, UK. Retrieved from www.id21.org/society/insights62art4.html

Mnguni, E. M., \& Giampicolli, A. (2016) Community-based Tourism and Food: Towards a Relationship Framework. African Journal of Hospitality, Tourism and Leisure, 5(1), 1-12.

Mshenga, P. M. (2010). Tourism and Agriculture Linkages: Determinants of Local Agricultural Products Purchase by Hotels at the Kenyan Coast, Research Application Summary Second REFORM Biennial Meeting. 20-24 September 2010, Entebbe, Uganda.

Mshenga, P. M., \& Owuor, G. (2009). Opportunities for Micro and Small Scale Business in the Tourism Sector: The Case of the Kenya Coast. KCA Journal of Business Management, 2, 52-68.

Mtapuri, O., \& Giampiccoli, A. (2016). Towards a Comprehensive Model of Community-based tourism

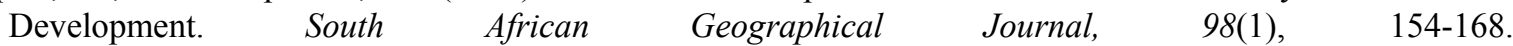
https://doi.org/10.1080/03736245.2014.977813

Office of Chief Government Statistics [OCGS]. (2013). Statistical Report on Socio-Economic Survey 2012. Office of Chief Government Statistician (OCGS), Zanzibar.

Okech, R. N. (2010). Tourism development in Africa: Focus on poverty alleviation. The Journal of Tourism and Peace Research, l(1). Retrieved from http://www.icptr.com/wp-content/uploads/2010/05/Okech-Tourism-development-in-Africa-25-05-10.pdf

Revolution Government of Zanzibar [RGZ]. (2004). Ministry of Tourism Trade and Investment. Zanzibar Tourism Policy Statement, Zanzibar. Retrieved from www.zanzibartourism.net/docs/policystatement.pdf

Revolutionary Government of Zanzibar [RGZ]. (2009). Zanzibar Human Development Report. Towards pro poor growth. Revolutionary Government of Zanzibar (SMZ), Zanzibar.

Revolution Government of Zanzibar [RGZ]. (2010). The Zanzibar Strategy for Growth and Reduction of Poverty (ZSGRP II): Revolutionary Government of Zanzibar, Zanzibar.

Revolutionary Government of Zanzibar [RGZ]. (2016). The Zanzibar Strategy for Growth and Reduction of Poverty III 2016-2020 (ZSGRP III): Revolutionary Government of Zanzibar, Zanzibar.

Rimal, A., \& Onyango, B. (2011). Purchasing Locally Produced Fresh Vegetables: National Franchise Vs. Locally Owned and Operated Restaurants. Retrieved from http://ageconsearch.umn.edu/bitstream/103464/2/AAEA_Manuscrpt_2011.pdf

Rogerson, C. (2012). Strengthening Agricultural Tourism Linkages in the Developing World: Opportunities, Barriers and Current Initiatives. African Journal of Agricultural Research, 7(4), 616-623.

Rueegg, M. (2009). The Impact of Tourism on Rural Poverty through Supply Chain Linkages to Local Food Producers in the Bolivian Altiplano. Dissertation for Award of MSc Degree at London School of Economics, Political Science.

Steck, B., Wood, K., \& Bishop, J. (2010). Tourism More Value for Zanzibar: Value Chain Analysis: Final Report, February 2010. Zanzibar: VSO, SNV and ZATI.

Timms, B. F., \& Neill, S. (2011). Cracks in the Pavement: Conventional Constraints and Contemporary Solutions for Linking Agriculture and Tourism in the Caribbean. In R. Torres \& J. Momsen (Eds.), Tourism and 
Agriculture: New Geographies of Production and Rural Restructuring. London: Routledge.

Torres, R., \& Momsen, J. (2011). Introduction. In R. Torres \& J. Momsen (Eds.), Tourism and Agriculture: New Geographies of Production and Rural Restructuring (p. 9). London: Routledge. https://doi.org/10.1183/1025448x.10012611

United Republic of Tanzania [URT]. (2010). Tanzania Agriculture and Food Security Investment Plan (TASFIP) 2011-12 to 2020-21. Dar es Salaam: Government Printer.

United Republic of Tanzania [URT]. (2003). Indicative Tourism Master Plan for Zanzibar and Pemba, Dublin, Ireland. Retrieved from www.zanzibartourism.net/docs/masterplan.pdf

Voluntary Service Overseas [VSO]. (2015). Value Chain Analysis of the Fruit and Vegetable Market for Smallholder Farmers in Zanzibar. Volunteer Services Overseas, Dar Es Salaam.

Voluntary Service Overseas [VSO]. (2013). Commercial Agriculture for Smallholder farmers in Zanzibar (CASH).

Retrieved

from http://www.ivoindia.org/Images/tanzania-commercial-agriculture-for-smallholder-farmers-in-zanzibar-engli sh_tcm78-40034.pdf

Zanzibar Association of Tourism Investors [ZATI]. (2009). Zanzibar Agricultural Transformation Initiative for Sustainable Development, 2010-2020 for Agricultural Productivity, Food Security and Sustainable Livelihood. Retrieved from http://www.kilimoznz.or.tz/images/Agrictransform.pdf

Zanzibar Association of Tourism Investors [ZATI]. (2011). Tourist database. Accessed in Tanzania tourist board statistics. Zanzibar Commission for Tourism. Retrieved from www.zanzibartourism.net/news.php

\section{Copyrights}

Copyright for this article is retained by the author(s), with first publication rights granted to the journal.

This is an open-access article distributed under the terms and conditions of the Creative Commons Attribution license (http://creativecommons.org/licenses/by/4.0/). 